\title{
Student's Satisfaction Toward the Implementation of Contextual Approach in Educational Statistics Online Tutorial
}

\author{
Mery Noviyanti \\ Open University, Indonesia \\ merrynov@gmail.com
}

Published online: 29 July 2019

To cite this article: Noviyanti M. 2019. Student's satisfaction toward the implementation of contextual approach in educational statistics online tutorial. Malaysian Journal of Distance Education 21(1): 1-16. https://doi.org/10.21315/mjde2019.21.1.1

To link to this article: https://doi.org/10.21315/mjde2019.21.1.1

\begin{abstract}
This research was done due to the lack of students' participation in an online tutorial implementation of Education Statistics course. In addition, the students' learning result of this course was categorised as low. Appropriate learning strategy to understand the material was adopting a contextual approach on the online tutorial implementation. This paper discussed about students' satisfaction toward the online tutorial implementation of education statistics course by using a contextual approach related to the quality of tutors, the learning process and the students' learning result. Besides, this paper analysed the gap between the students' needs and satisfaction on the implementation of the online tutorial. The subjects of this research were 37 active college students who took the tutorial in their second semester in 2015. It was analysed using descriptive qualitative method. This research used Importance Performance Analysis (IPA). IPA which consists of two components: quadrant analysis and gap analysis. The result showed that gap analysis result for "Satisfaction toward Applied Learning Model" was good. Respondents were quite satisfied with tutor's ability in explaining material of tutorial related to daily life, tutor's ability in providing illustrations/examples contextually, and tutor's ability in solving exercises which is related to daily life. In addition, $84 \%$ of students who took this tutorial got a minimum grade of $\mathrm{C}$. This showed that students were satisfied enough with the given model and contextual approach was appropriate to be applied to online tutorial of education statistics course.
\end{abstract}

Keywords: education statistics, contextual approach, satisfaction, online tutorial

(C) Penerbit Universiti Sains Malaysia, 2019. This work is licensed under the terms of the Creative Commons Attribution (CC BY) (http://creativecommons.org/licenses/by/4.0/). 


\section{Introduction}

Statistics is a scientific method of collecting, organising, analysing, describing, and interpreting data, as well as making a valid conclusion based on the performed analysis and rational decision (Herryhyanto, 2008). Statistics consists of various applications, including the field of education named Education Statistics.

Similar to the common mathematical problems, learning statistics requires concrete learning processes. Brown, Collins and Duguid in Jones et al. (2001) revealed that the analysis and interpretation of the data is a part of the difficult thing in statistical thinking because it depends on contextual situations that may not be familiar to the learners.

Online tutorials for Education Statistics course was not going well, it is reinforced by Noviyanti (2006) who mentions that the students' participation of Faculty of Teacher Training and Education who take the tutorial online is less than 5\%. It is also reinforced by Rustam (2015) who confirms that the students desperately need the tutor's seriousness in the online tutorial implementation. Mastery of the material, feedback towards students' tasks and students' responses in discussion forum are important aspects that students need.

The learning result of Mathematics Education showed that students who had a grade below or equal to the grade of $\mathrm{C}$ were $87 \%$. In addition, the researchers had conducted an interview with two students about the problems in studying the Education Statistics course. It was said that the students had difficulty in compiling the data into tables and charts as well as analysing and interpreting the data. Moreover, they had difficulty to learn the material of normal curve and the other curves because it was not applied in their daily life. Other problems experienced in understanding the Education Statistics material where they have to study the material independently and the material was difficult to be understood. Therefore, they need help in learning (tutorial) with a good learning model to assist them in understanding the material of the course.

One way to overcome this issue is by applying contextual approach on the online tutorial. The tutorial is oriented to the relevance of statistical concepts 
and daily life, as well as re-applying the concept that has been owned by the students to resolve the issue.

This paper discusses students' satisfaction toward the online tutorial implementation of education statistics course by using a contextual approach related to the quality of tutors, the learning process, and the students' learning result. Besides, this research analyses the gap between the students' needs and satisfaction of the online tutorial implementation.

\section{Literature Review}

\section{Contextual Approach of Education Statistics}

Contextual approach is a learning strategy which does not require the students to memorise facts, but a strategy which encourages students to construct some knowledge in their own mind. The contextual approach is a conception that helps lecturer to link the content of the course to the real situation and motivates students to create a connection between knowledge and its application in their daily life (Trianto, 2009).

In order to implement the contextual learning, a lecturer links the material that will be taught to the students' real world and encourage the students to relate the knowledge they owned to its application in their daily life by using seven main components of contextual approach, they are i) constructivism; ii) independent learning groups; iii) inquiry; iv) questioning; v) modelling; vi) reflection; vii) authentic assessment (Departemen Pendidikan Nasional, 2008).

Statistics Education with PEMA4210 code contains basic concepts of statistics; data summary, presentation of data, normal distribution, hypothesis testing, comparison of the mean and the proportion for the group of data, confidence intervals, comparison of median values for more than two groups of data, correlation analysis, and simple linear regression analysis. General competence of this course is that students are able to use some of the statistical methods to present data, analyse parameter estimation data, test hypothesis, and make the conclusion. 
In learning statistic, it needs a learning method that links to the material that will be taught with the students' real world of and encourage them to make the relation between the knowledge they have and its application in their daily life. The tutorial activities emphasise students to achieve academic understanding within or outside the school context through solving real or situated problems.

\section{Online Tutorial}

An online tutorial is internet-based tutorial services or Web-Based Tutorials (WBT) which is managed by the Open University and can be attended by students through internet network. The material provided in the form of text tutorials that can be accessed by the students wherever they are, without having to meet directly with a tutor. In this model, the tutor should prepare a script tutorial that allows the interaction between tutor and students. An online tutorial is organised through the internet by using the software Moodle. An online tutorial is held for eight weeks. It started after the closure of the registration period and the registration is begun coincided with the course registration. Online tutorial activities consist of:

1. distribution of initiation material from the tutor to the students as much as eight times (1 initiation material per week),

2. provision of at least three tasks that must be done by the students, and

3. questions and answers activities between tutors and students as well as among the students.

\section{Student's Satisfaction}

The word "satisfaction" is derived from the Latin "satis" (means good enough, adequate) and "facio" (do or make). According to Srinadi (2008), students' satisfaction is a state of fulfillment of desires, hopes, and needs of students. Students' satisfaction is a positive attitude towards higher education institutions service since there is congruence between the expected service and the received service (Sopiatin, 2010). According to Srinadi (2008), students' satisfaction is a state of fulfillment of desires, hopes, and needs of students. Meanwhile, Sarjono (2007) defines students' satisfaction as a comparison between the desired expectations of students about the service employees, the competence of lecturers supported by tools. 
According to Noermijati (2010), there are five dimensions of service quality, i.e. tangible (physical evidence), reliability, responsiveness, assurance, and empathy. The five dimensions will be explained as follows:

1. tangible (physical evidence) means that the students require the existence of evidence that can be shown as matters relating to timeliness, convenience, friendliness, and its interaction with the students.

2. reliability in the sense of a reliable tutor for doing the tasks that become the rights of students.

3. responsiveness means the tutor must have the responsiveness to complaints and needs of students.

4. assurance in the sense that the tutor must have the knowledge, competence, courtesy, and trustworthiness, free from danger, risk, or doubt.

5. empathy includes the convenience for students to establish relationships and good communication.

\section{Research Methods}

The subjects of this research are active college students who took the tutorial as much 37 people. The satisfaction instruments (Table 1) are designed by referring to "the 5 service dimensions all customers care" found at http:// www.serviceperformance.com/the-5-service-dimensions-all-customerscare-about/\#sthash.1F3s4cME.dpuf.

Table 1 Indicator of instrument

\begin{tabular}{|c|c|c|}
\hline Variable & $\begin{array}{l}\text { Sub-variable } \\
\text { (Dimension) }\end{array}$ & Indicator \\
\hline \multirow{5}{*}{$\begin{array}{l}\text { Students' Needs- } \\
\text { Satisfaction }\end{array}$} & Reliability & Tutor's quality in performing tutorial \\
\hline & Responsiveness & $\begin{array}{l}\text { Tutor's quality in responding the situation } \\
\text { of the students so that they can attend the } \\
\text { tutorial activities in class well. }\end{array}$ \\
\hline & Assurance & $\begin{array}{l}\text { The quality of tutor's ability in explaining } \\
\text { the material of tutorial. }\end{array}$ \\
\hline & Empathy & $\begin{array}{l}\text { Tutor's willingness in paying attending to } \\
\text { the students individually }\end{array}$ \\
\hline & Tangible & Implemented learning model \\
\hline
\end{tabular}


Data collection was performed by spreading an online questionnaire and documentation study. An online questionnaire was given at the beginning of the tutorial to find out the students' needs. As for knowing satisfaction regarding the implementation of the tutorial, the questionnaire was also given at the end of the tutorial. The contents of both questionnaires were the same. This was done to determine the gap between students' needs and satisfaction regarding the tutorial implementation. In addition, the documentation study was also conducted on task, discussions and final value at the registration period of February 2015.

This research used Importance Performance Analysis (IPA). IPA consisted of two components: quadrant analysis and gap analysis. Quadrant analysis was used to see students responses associated with the implementation of the online tutorial, while the gap analysis was used to observe the gap the level of needs and satisfaction of the students.

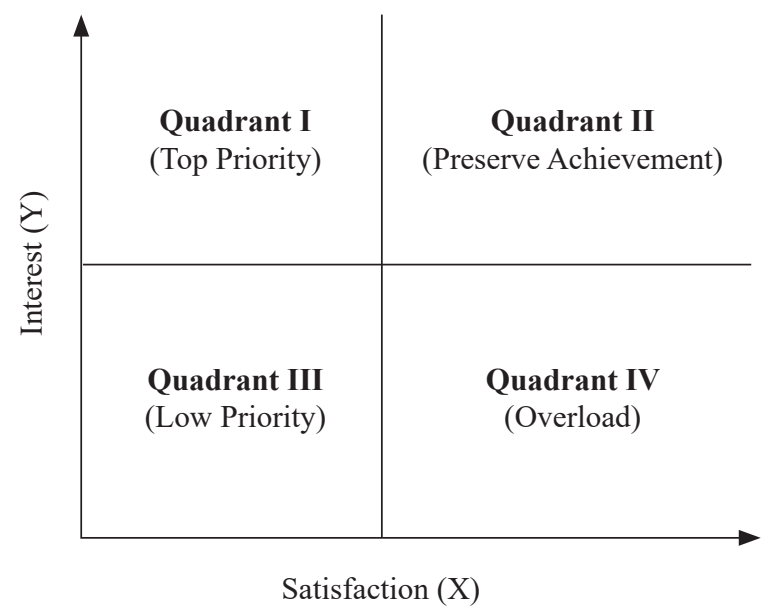

Figure 1 Quadrant analysis of interest-satisfaction

The diagram (Figure 1) consists of four quadrants (Supranto, 2001). Quadrant I (Top Priority): it contains services that were important to the students, but, the service had not been satisfied yet. The satisfaction level was lower than the level of students' interest to the service. The services contained in this quadrant must be improved in order to satisfy the students. Quadrant II (Preserve Achievement): products of the services in this quadrant indicates that the services were important and satisfying. These service products need 
to be preserved for the next time. Quadrant III (Low Priority): products of the services in the quadrant were considered less important by students and the fact showed that students satisfaction was also low. Improved provision of services in this quadrant might be reconsidered because of its effect on the benefits perceived by the students was very small. Quadrant IV (Overload): this quadrant includes services that were considered less important by students.

\section{Result and Discussion}

\section{Students'Satisfaction}

From the questionnaires distributed, there are 37 people who gave the response to the online questionnaire. The results of respondents' assessment to the tutorial implementation were captured using a questionnaire enclosed with five options for each questions (scale 1-5) with the following criteria: $1=$ very dissatisfied; $2=$ dissatisfied; $3=$ neutral; $4=$ satisfied and $5=$ very satisfied. Respondents were asked to assess the level of need and the level of satisfaction with each item statement. In general, students' perceptions of the planning and implementation of the tutorial was quite good with the average (mean) value approaching the scale of 4 (satisfied).

\section{Satisfaction toward Tutor's Quality}

Summary of respondent satisfaction level toward the tutor's quality are presented in Table 2.

Table 2 Satisfaction level on tutor quality

\begin{tabular}{lccc}
\hline Questions & $\begin{array}{c}\text { Mean } \\
\text { Needs }\end{array}$ & $\begin{array}{c}\text { Mean } \\
\text { Satisfactions }\end{array}$ & Differences \\
\hline 1. Tutor's qualification for the material & 4.39 & 3.85 & -0.54 \\
2. The availability for tutorial plans & 4.39 & 3.85 & -0.54 \\
$\begin{array}{l}\text { 3. The availability for the initiation } \\
\quad \text { material regarding daily life }\end{array}$ & 4.43 & 4.5 & 0.07 \\
$\quad$ Average & 4.40 & 4.07 & -0.34 \\
\hline
\end{tabular}


Generally, on the components of satisfaction with the quality of tutors in carrying out the tutorial, average satisfaction level of the respondent is high at 4.07. The results of the gap between needs and satisfaction regarding the "availability of materials related to the initiation of daily life" get a positive result of 0.07 . This indicates that learning by using a contextual approach that is applied fulfill the needs of the students. However, there was quite a high gap for "Tutor qualification for the material" and "The availability for tutorial plans" as of -0.54 .

In general, tutor with higher qualification have better quality. Educator qualification has been regulated in Government Regulation Number 19, 2005 concerning Education National Standard chapter VI article 28 which reads that educator should have academic and competency qualifications as the agent of learning, physically and mentally healthy, and having the ability to realise the national purpose. Meanwhile, Daryanto (2013) stated that effort in improving teacher professionalism amongst them is through (i) qualification improvement and higher educational level requirement for educator, (ii) certification programme. According to Alim's (2013) research result, there was significant influence from education qualification toward educator competency toward teaching quality with 0.388 correlation coefficient and effective contribution of $15.05 \%$. Meanwhile, Narni's (2012) research result stated that there was 35 positive and significant relationship between academic qualification toward teacher performance as of $0.303 \%$ and $9.2 \%$ contribution.

Based on research result and actual tutor qualification, then Institution should immediately conduct tutor recruitment according to higher qualification.

\section{Participants}

Summary of respondent satisfaction level toward tutor's quality in responding the tutorial participants' situation is given in Table 3 as follows: 
Table 3 Satisfaction level on tutor quality

\begin{tabular}{lccc}
\hline Questions & $\begin{array}{c}\text { Mean } \\
\text { needs }\end{array}$ & $\begin{array}{c}\text { Mean } \\
\text { satisfaction }\end{array}$ & Differences \\
\hline 4. $\begin{array}{l}\text { Tutor's ability in directing the } \\
\text { participants' attention to the discussed } \\
\text { topic }\end{array}$ & 4.41 & 4.00 & -0.41 \\
$\begin{array}{l}\text { 5. Tutor's sensitivity in responding the } \\
\text { participants' difficulties }\end{array}$ & 4.30 & 4.00 & -0.30 \\
$\begin{array}{l}\text { Tutor's ability in inviting participants } \\
\text { to participate in a discussion }\end{array}$ & 4.51 & 3.51 & -1.00 \\
$\begin{array}{l}\text { Tutor's ability in receiving some } \\
\text { critiques and advices from the } \\
\text { participants }\end{array}$ & 4.39 & 4.2 & -0.19 \\
\hline
\end{tabular}

Based on the component of tutor's quality in responding the participants' situation, the respondent satisfaction level is quite high. Averagely, the satisfaction level is counted on 3.93. Comparing to the needs level, the satisfaction level of the respondents for all items are below the needs level according to the respondent. Rustam (2015) found that $15 \%$ of the students were quietly dissatisfied with how tutor was being active in the tutorial. There are $19 \%$ of the students are dissatisfied with tutor's ability in moderating the discussion. However, based on the results, it can be seen that there are several tutors that are not active in guiding the students, especially in responding a discussion.

Low satisfaction is noted by students to the aspect of "tutor's ability in inviting participants to participate in discussion". The students really need some interaction with their tutor. It means the students hope that the tutor can encourage and motivate them to be more active in the discussion.

\section{Satisfaction Toward the Quality of Tutor's Ability in Giving Explanation}

Summary of respondent satisfaction level toward the quality of tutor's ability in explaining material of tutorial is given in Table 4 . 
Table 4 Satisfaction level on tutor abilities' quality to explain materials

\begin{tabular}{lccc}
\hline Questions & $\begin{array}{c}\text { Mean } \\
\text { needs }\end{array}$ & $\begin{array}{c}\text { Mean } \\
\text { satisfaction }\end{array}$ & Differences \\
\hline $\begin{array}{l}\text { 8. } \begin{array}{l}\text { Tutor's ability in answering students' } \\
\text { questions }\end{array} \\
\begin{array}{l}\text { Tutor's ability in asking directed } \\
\text { questions to help students to } \\
\text { understand the concept }\end{array}\end{array}$ & 4.30 & 4.00 & -0.30 \\
$\quad$ Average & 4.91 & 0.09 \\
\hline
\end{tabular}

The level of tutor's ability in answering questions and asking directed questions which help students to understand the concept has satisfaction value 4. This is a better result compared to Noviyanti's research that was conducted in 2015 which stated that tutor's ability in mastering material is 3.39 and the students' satisfaction in easiness of understanding material is 3.01. Tutors in Rustam's research (2015) did not apply the conceptual model.

\section{Satisfaction toward Applied Learning Model}

Summary of respondent satisfaction level toward the quality of tutor's ability in explaining material of tutorial is given in Table 5 .

Table 5 Satisfaction level toward applied learning model

\begin{tabular}{lccc}
\hline Questions & $\begin{array}{c}\text { Mean } \\
\text { needs }\end{array}$ & $\begin{array}{c}\text { Mean } \\
\text { satisfaction }\end{array}$ & Differences \\
\hline $\begin{array}{l}\text { 10. Tutor's ability in explaining material of } \\
\text { tutorial related to daily life }\end{array}$ & 4.10 & 4.40 & 0.30 \\
$\begin{array}{l}\text { 11. Tutor's ability in providing illustrations/ } \\
\quad \text { examples contextually }\end{array}$ & 4.00 & 4.50 & 0.50 \\
$\begin{array}{l}\text { 12. Tutor's ability in solving exercises which is } \\
\text { related to daily life }\end{array}$ & 4.00 & 4.00 & 0.00 \\
\multicolumn{1}{c}{ Average } & 4.03 & 4.30 & 0.27 \\
\hline
\end{tabular}

Based on the quality of tutor's ability component in explaining the material, the respondent satisfaction level is quite high. Students are satisfied enough of the tutor's ability in relating the material to daily life. In Education Statistics tutorial, the contextual approach can be done by using data which 
are used and usually have been used in daily life, e.g. learning location size (median, quartiles, deciles, and percentiles). Understanding about location size is very useful when students need values of a frequency distribution of parents' income. Another example can involve students to learn variation level which is related to stock price. Students are involved as if they are an investor. The varied stock prices attract brave investors to take a risk because it has a big chance in getting the benefit, although it can also make a big loss. Therefore, besides mean value, variation value is also needed to represent a group of value. For tutor who does not use contextual, satisfaction about accuracy method/ given tutorial model is only 3.12.

\section{Satisfaction toward Tutor's Willingness in Giving Attention to Participants}

Summary of respondent satisfaction level toward tutor's willingness in giving attention to participants individually is given in Table 6 .

Table 6 Satisfaction level toward tutor's willingness in giving attention to participants individually

\begin{tabular}{lccc}
\hline Questions & $\begin{array}{c}\text { Mean } \\
\text { needs }\end{array}$ & $\begin{array}{c}\text { Mean } \\
\text { satisfaction }\end{array}$ & Differences \\
\hline $\begin{array}{l}\text { 13. Tutor's willingness in managing } \\
\text { difficulties that are faced by participants }\end{array}$ & 4.38 & 4.25 & -0.13 \\
$\begin{array}{l}\text { 14. Tutor's willingness in serving } \\
\text { participants individually }\end{array}$ & 4.24 & 3.89 & -0.35 \\
$\begin{array}{l}\text { 15. Tutor's willingness in serving } \\
\text { participants out of tutorial schedule }\end{array}$ & 4.03 & 3.73 & -0.3 \\
\hline \multicolumn{1}{c}{ Average } & 4.22 & 3.96 & -0.26 \\
\hline
\end{tabular}

Satisfaction level of tutor's willingness in giving attention to participants individually is quite low. This condition implies that students are expecting the tutor to have more emphatic toward difficulties that are faced by students in tutorial and learning. Based on the value they give, they surely expect more attentions and helps from tutors to help them to solve the problem they face. 


\section{Tutor's Satisfaction toward Tools and Infrastructures}

Summary of respondent toward tools and infrastructures is given in Table 7.

Table 7 Satisfaction level on facilities and infrastructures

\begin{tabular}{lccc}
\hline Questions & $\begin{array}{c}\text { Mean } \\
\text { needs }\end{array}$ & $\begin{array}{c}\text { Mean } \\
\text { satisfaction }\end{array}$ & Differences \\
\hline 16. Easiness of using online tutorial features & 4.50 & 3.50 & -1.00 \\
17. Easiness of accessing online tutorial & 4.50 & 3.00 & -1.50 \\
\hline Average & 4.50 & 3.25 & -1.25 \\
\hline
\end{tabular}

Easiness of tutorial access becomes very important because it relates to students' motivation in participating online tutorial. Susanti (2007) stated that the lack of students' motivation and participation is caused by tutor's delays in showing initiation material and responding discussion, and also network disturbance so that activation process and the website access take longer time.

\section{Students' Result}

According to Winkel (1996), learning result is a proof of success that has been reached by participants where every learning process can cause a special change. After performing tutorial, all students were facing Final Semester Test. There were 98 students took final semester test on subject statistics and there were 37 students took online tutorial. Based on the test result, the good results can be seen in Table 8 .

Table 8 Student's study result

\begin{tabular}{lcccccc}
\hline \multirow{2}{*}{ Number of students } & \multicolumn{7}{c}{ Grade/person } & \multirow{2}{*}{ Total } \\
\cline { 2 - 6 } & $\mathrm{A}$ & $\mathrm{B}$ & $\mathrm{C}$ & $\mathrm{D}$ & $\mathrm{E}$ & \\
\hline Attending tutorial & 8 & 8 & 15 & 6 & 0 & 37 \\
Do not attending tutorial & 0 & 8 & 20 & 25 & 8 & 61 \\
\hline
\end{tabular}

There are $84 \%$ students who attend the tutorial get minimal C. Achievement of learning purpose which in form of learning accomplishment is the result of all learning activity (Arikunto, 2009). In other words, the quality of learning activity is the only defining factor for the result. Achievement test 
usually evaluates what the students get after they are given one subject. In arranging learning achievement test, efforts are used to decide knowledge and skills which have been taught in several grades and every item of a test is provided for material assessment. Based on the result, it can be indicated that contextual approach in application is proper to be used for online tutorial on statistics subject.

\section{Quadrant Analysis}

Cravens (2013) stated that to reach high satisfaction level, it is needed understanding about what consumers want from an institute to fulfill the related consumer need. This indicates that students' satisfaction is started from understanding what students want. One thing that is needed by students is good services, started the registration process, lectures, test to complete the study. To support that, it needs a proper plan, adequate facilities and supporting human resource (Supranto, 2011). This quadrant analysis is used to know the consumer responds toward plotted aspects based on interest and satisfaction levels of every aspect. Based on this quadrant analysis, we can see that the every variable place is located in a different quadrant, so we can see what variables that are needed to be improved and get more attention.

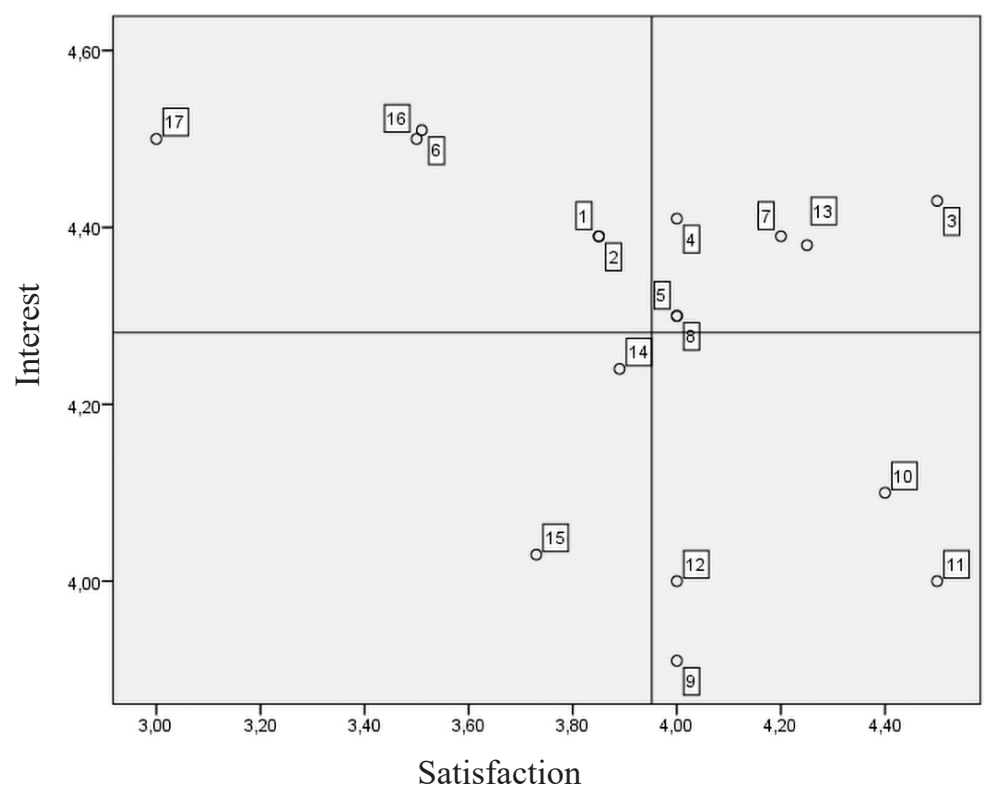

Figure 2 Analysis quadrant 
In this research (Figure 2), there are five services aspects that exist in Quadrant I. Service aspect which is located in this quadrant is considered as the important factor and or is expected by students, but at this time it is not satisfying yet so that tutor must work on that various factors. Factors which are located in this quadrant are a priority that must be improved. One of the factors is tutor qualification in accordance with the tutorial subject.

In Quadrant II, there are five aspects. Two of them are tutor's ability in directing participants' attention to the discussed topic and tutor's sensitivity in handling difficulties which are faced by participants. Aspects located in this quadrant are considered important and expected as supporting factors for students' satisfaction so that tutor has to make sure in maintaining the achievement.

Tutor's willingness to serve participants individually and tutor's willingness to serve participants out of schedule contain in Quadrant III. Aspects located in this quadrant have low interest and satisfaction levels, and they are considered not so important and or not so expected by consumers. However, the tutor must improve all services to increase the students' satisfaction. Aspects in this quadrant are considered as not really important aspects by students and in fact, the students' satisfaction is low.

From Quadrant IV, most are consist of satisfaction toward tutor's willingness in giving attention to participants individually. Factors located in this quadrant are considered as not so important and not so expected aspects, so tutor needs to allocate bound factors sources with other factors which have higher priority which still need improvement.

\section{Conclusion}

Applying contextual approach of the online tutorial on statistics subject gets positive respond from students. It is seen from the results of the questionnaire which states that students are satisfied with the material initiation exercise and discussion is given by tutor. They are satisfied with learning process which relates the material to daily life. The contextual approach applied in this tutorial can improve students in the understanding material. However, the low satisfied value is given by students toward "tutor's ability in 
involving participants to participate in the discussion" aspect. This shows that students are still expecting the tutor to push or motivate students to get involved actively in discussion.

\section{References}

Alim, S. 2013. Pengaruh kualifikasi pendidikan, keikutsertaan diklat dan sikap pada profesi terhadap kompetensi guru PAI SD di Kabupaten Pekalongan. Abstrak (online) IAIN Walisongo.

Arikunto, S. 2009. Dasar-dasar evaluasi pendidikan. Jakarta: Bumi Aksara.

Borden, V. M. H. 1995. Segmenting student markets with a student satisfaction and priorities survey. Research in Higher Education 36(1): 73-88.

Cravens, D. 2013. Strategic marketing 10th edition. New York: McGraw-Hill International Edition.

Daryanto, E. 2013. Preparing modules: teaching materials for teacher preparation in teaching. Yogyakarta: Gava Media.

Departemen Pendidikan Nasional. 2008. Modul Pendamping Perangkat tutorial (Better Education through Reformed Management and Universal Teacher Upgrading) BERMUTU. Jakarta: Direktorat Ketenagaan Direkorat Jenderal Pendidikan Tinggi.

Elliot, K. M. and M. A. Healy. 2001. Key factors influencing student satisfaction related to recruitment and retention. Journal of Marketing for Higher Education 10: 1-11.

Elliott, K. M. 2003. Key determinants of student satisfaction. Journal of College Student Retention 4(3): 271-279.

Herryhyanto. 2008. Statistika dasar. Jakarta: Universitas Terbuka.

Jamelske, E. 2009. Measuring the impact of a university first-year experience program on student GPA and retention. Higher Education 57(3): 373-391.

Jones, G. A., C. W. Langrall, C. A. Thornton, E. S. Mooney, A. Wares, M. R. Jones, et al. 2001. Using students' statistical thinking to inform instructions. Journal of Mathematical Behavior 20(1): 109-144.

Narni, Iriyana Rahwi. 2012. Kontribusi Intensitas Kegiatan Kelompok Kerja Guru (KKG), Pelatihan-Pelatihan, dan Kualifikasi Akademik terhadap Kinerja Guru Sekolah Dasar di Kecamatan Pengaron Kabupaten Banjar. PhD diss. Yogyakarta: Universitas Negeri Yogyakarta.

Noermijati. 2010. Kajian tentang kepuasan mahasiswa terhadap kebijakan dosen di Fakultas Ekonomi Unibraw. Journal of Management Business Review 7(1): $33-$ 43.

Noviyanti, M. 2006. Laporan penelitian kesiapan tutor Universitas Terbuka dalam memanfaatkan fasilitas tutorial online. Jakarta: Universitas Terbuka.

Pascarella, E. T. and P. T. Terenzini. 2005. How college affects students: A third decade of research, Vol. 2. San Francisco: John Wiley \& Sons.

Rustam. 2015. Laporan penelitian evaluasi penyelenggaraan tutorial online program Studi S1 Pendidikan Matematika. Jakarta: Universitas Terbuka. 
Sarjono, Y. 2007. Faktor-faktor strategik pelayanan dosendan dampaknya terhadap kepuasan mahasiswa FKIP Universitas Muhamadiyah Surakarta tahun akademik 2005-2006. Varidika 19(1): 66-74.

Sopiatin, P. 2010. Manajeman belajar berbasis kepuasan siswa. Bogor: Ghalih Siswa.

Srinadi. 2008. Faktor-faktor penentu kepuasan mahasiswa terhadap pelayanan fakultas sebagai Lembaga Pendidikan (Studi Kasus di FMIP, Universitas Udayana). Jurnal Cakrawala Pendidikan November. Th. XXVII.

Suparno, P. 2001. Teori perkembangan kognitif Jean Piaget. Yogyakarta: Kanisius.

Supranto, J. 2011. Pengukuran tingkat kepuasan pelanggan untuk menaikan Pangsa Pasar. Jakarta: Rineke Cipta.

Susanti. 2007. Pengaruh faktor internal mahasiswa terhadap partisipasi mahasiswa dalam tutorial online. Jurnal Pendidikan Terbuka dan Jarak Jauh 8(1): 68-82.

Trianto, 2009. Mendesain model pembelajaran inovetif-progresif (konsep, landasan, dan implementasinya pada Kurikulum Tingkat Satuan Pendidikan (KTSP). Jakarta: Kencana.

Universitas Terbuka. 2013. Pedoman penyelenggaraan tutorial tatap muka. Jakarta: Universitas Terbuka.

Winkel, W. S. 1996. Psikologi pendidikan. Jakarta: Grasindo. 